\title{
Perubahan Tari Rentak Kudo Dalam Kehidupan Sosial Masyarakat
}

\author{
Sintia Farsalena, Susi Fitria Dewi \\ Sintia.farsalena@yahoo.com \\ Universitas Negeri Padang
}

\begin{abstract}
This research has a purpose to identify: the impact of changing kudo ritual dance traditions in the social life of people in the village of debai jambi province. This type of research is qualitative descriptive. Sources ie primary data submitted by informants, data sources taken in the form of written notes coming from informants who were interviewed, documentation and literature study. The research findings reveal that the change of kudo rentak tradition in the social life of society in Debai village of Jambi Province has social and moral impact such as the behavior of less polite when dancing, drinking behavior, fights between youth when danced by kudo rentak dance, disturbance of society with Loud music. The social control of the village and community governments is so weak that they are unable to minimize the impact of the tradition.
\end{abstract}

Keywords: Tradition, Tari Rentak Kudo, social transformation

\begin{abstract}
Abstrak
Penelitian ini bertujuan mengidentifikasi: dampak perubahan tari rentak kudo dalam kehidupan sosial masyarakat Desa Debai Kota Sungai Penuh. Jenis penelitian ini adalah kualitatif deskriptif. Sumber yaitu data primer yang disampaikan oleh informan, dokumentasi dan studi kepustakaan. Temuan penelitian mengungkapkan bahwa perubahan tradisi tari rentak kudo dalam kehidupan sosial masyarakat di Desa Debai Provinsi Jambi memiliki dampak sosial dan moral seperti adanya perilaku kurang sopan saat menari, perilaku minumminuman keras, perkelahian antar pemuda saat diadakan acara tari rentak kudo, dan terganggunya masyarakat dengan musik yang keras. Kontrol sosial dari pemerintah desa dan masyarakat sangat lemah sehingga tidak mampu meminimalisir dampak dari tradisi tersebut.

Kata Kunci : Tradisi, Tari Rentak Kudo, Perubahan social
\end{abstract}




\section{Pendahuluan}

Kota Sungai Penuh dibentuk berdasarkan Undang-Undang Republik Indonesia Nomor 25 Tahun 2008 merupakan pemekaran dari Kabupaten Kerinci, pengesahannya dilakukan oleh Menteri Dalam Negeri pada tanggal 8 Oktober 2009. Suku Kerinci termasuk dalam kategori melayu dan paling dekat dengan kebudayaan Minangkabau dan Melayu Jambi. Sungai Penuh dan Kerinci memiliki kesamaan dari segi bahasa dan adat-istiadat dan lainnya serta kesenian yang sangat kaya, salah satunya adalah kesenian Tari Rentak Kudo. Tarian Rentak Kudo merupakan sebuah tradisi tari yang berasal dari Hamparan Besar Tanah Rawang, pada zaman dahulu hanya ditampilkan pada acara-acara kebesaran tertentu saja dan berbau mistik. Rentak Kudo mulai berkembang diperkirakan pada tahun 1970, sebelumnya tari Rentak Kudo ditarikan oleh anak-anak yang belajar silat tradisional di hamparan rawang bagian tengah dengan nama Tari Sbuk Tanguo (sapu tangan) dengan gerakan khusus pencak silat langkah tiga. Gerakan tarian ini menyerupai langkah silat yang menyerupai gerakan hentakan kaki kuda ke tanah yang diiringi oleh alunan musik yang berirama gembira, dengan tujuan untuk menghidupkan gerakan tari yang dilakukan oleh penari dan membuat penonton tertarik untuk ikut menari dan berdendang.

Dalam pertunjukkannya, kesenian tari rentak kudo ini terdiri dari iringan instrumen gendang, musik vokal, dan bentuk tari tradisional. Iringan instrument gendang ini memainkan beberapa motif gendang, sedangkan musik vokal membawakan berbagai jenis lagu yang digunakan untuk tarian rentak kudo, lagu yang dinyanyikan adalah lagu khas Kota Sungai Penuh. Alat musik yang biasa digunakan adalah 2 buah gendang rebana, 1 botol kaca dan 1 sendok yang digunakan untuk memukul botol. Tempat pertunjukan yang sering digunakan adalah di lokasi atau ruangan yang cukup besar, kemudian tempat yang digunakan ini sengaja dikosongkan yang akan digunakan sebagai ruang bebas untuk para pemain musik dan para penari, sedangkan posisi penonton melingkar, memfokuskan perhatian ke tarian rentak kudo yang disajikan. Dahulu antara penari laki-laki dan perempuan dipisah dengan cara penari perempuan berada di barisan depan, sedangkan penari laki-laki berada di barisan belakang.

Berdasarkan temuan di lapangan, dapat disimpulkan bahwa Tari Rentak Kudo sudah menjadi keharusan bagi masyarakat Kota Sungai Penuh dalam setiap acara. Seperti pesta perkawinan, kenduri sko, dan acara hiburan rakyat lainnya. Keberadaan tari ini terus dijaga dari generasi ke generasi, baik itu masyarakat yang berada di Kota Sungai Penuh maupun yang berada di luar daerah Kota Sungai Penuh atau perantau, akan tetapi, unsur-unsur tradisional yang terdapat di dalam Tari Rentak Kudo tersebut 
Sintia Farsalena, Susi Fitria Dewi

Perubahan Tari Rentak Kudo Dalam Kehidupan Sosial Masyarakat

mulai memudar seiring berjalannya waktu dan mengalami perubahan dalam pelaksanaannya.

\section{Metode Penelitian}

Penelitian ini adalah jenis penelitian kualitatif dengan metode kualitatif deskriptif yaitu metode yang menggambarkan, menentukan dan menafsirkan suatu fenomena yang terjadi dalam masyarakat sesuai dengan objek apa adanya. Menurut Nasution (1992) metode kualitatif merupakan kegiatan dalam lilingkungan hidupnya, berinteraksi dengan mereka, berusaha memakai bahasa dan tafsiran mereka tentang dunianya. Dan menurut Lexy (2005) metode kualitatif sebagai prosedur penelitian yang menghasilkan data deskriptif berupa kata-kata tertulis atau lisan dari orang-orang atau perilaku yang diamati.

Penelitian ini mendeskripsikan tentang Dampak Tradisi Tari Rentak Kudo Terhadap Kehidupan Sosial Masyarakat Desa Debai Kecamatan Kumun Debai. Dalam penelitian ini penentuan informasinya yaitu dari informan atau orang orang yang memberikan informasi, seperti kepala desa, tokoh masyarakat yang terdiri dari Ninik mamak, masyarakat yang ikut menari, masyarakat yang tidak ikut menari, pemain orgen dan organisasi pemuda yang ada di Desa Debai, Data yang terkumpul, diolah dengan teknik analisis data yang digunakan, reduksi data, penyajian data, menarik kesimpulan.

\section{Hasil Penelitian dan Pembahasan}

\section{Perubahan Pelaksanaan Tradisi Tari Rentak Kudo Di Kehidupan Sosial Masyarakat Kerinci}

Widiyanti dan Waskita (1987) menyatakan bahwa perubahan sosial yang terjadi karena berbagai masalah sosial menimbulkan samar pola, dimana nilai-nilai hidup menjadi samar dan individu mengalami kebingungan dalam menentukan pegangan hidup. Hal yang dikemukakan ini di temukan di tengah masyarakat Desa Debai dalam hal pelaksanaan hiburan malam yang tidak mempunyai aturan dan sanksi yang jelas, sedangkan nilai-nilai agama dan adat istiadat yang menjadi patokan perilaku selama ini seolah samar dan tidak berlaku secara umum. Widiyanti dan Waskita (1987) mengemukakan bahwa samarnya norma membuat individu tidak memiliki norma yang seharusnya ada. Norma yang lama tidak mempunyai kekuatan, dan norma baru belum ada, sehingga timbulnya bentrokan satu sama lain. Hal inilah yang terjadi ketika dilaksanakannya acara Tari Rentak Kudo di Desa Debai dimana masyarakat tidak mempunyai norma yang jelas dan tegas mengenai pelaksanaan hiburan malam dan aturan mengenai perilaku dalam pelaksanaan Tradisi Tari Rentak Kudo. 
Norma baru yang seharusnya ada berupa peraturan desa atau peraturan khusus yang tertulis belum ada, sehingga terjadi bentrokan respon masyarakat mengenai dampak yang terjadi dalam pelaksanaan Tari Rentak Kudo. Berbagai bentuk perilaku remaja serta pemuda dalam acara Tari Rentak Kudo ini dapat berakibat buruk bagi para remaja yang berada dalam masa transisi dan mempengaruhi pembentukan jati diri mereka. Lingkungan ikut menentukan pembentukan identitas atau pribadinya. Bila lingkungan baik akan memungkinkan remaja menjadi baik, sedangkan lingkungan buruk bisa mendorong hal-hal yang negatif sebagaimana dikemukakan oleh Kartono (1990). Menurut Koentjaraningrat (2009) mengemukakan pendapat mengenai sikap sebagai berikut : sikap adalah suatu posisi atau keadaan mental didalam jiwa diri seseorang individu untuk bereaksi terhadap lingkungannya baik lingkungan manusia atau masyarakat lingkungan ilmiah maupun lingkungan fisiknya.

Perubahan-perubahan sosial yang serba cepat merupakan proses yang organis dan sangat dinamis serta kurangnya kesepakatan antara masing-masing anggota masyarakat mengakibatkan banyak individu yang menggunakan cara penyelesaian masalah "semau gue", acak-acakan dan anarkis (Kartono, 1990). Hal ini terlihat pada perubahan beberapa aspek di Tradisi Tari Rentak Kudo seperti di segi musik, lagu, waktu pelaksanaan, tempat pelaksanaan dan beberapa hal lainnya. Andreas et al., (2013) menyatakan bahwa Rentak Kudo versi lama berbeda dengan Rentak Kudo versi baru yang pada masa sekarang ini sangat digemari oleh semua kalangan masyarakat bahkan para anak muda. Rentak Kudo yang baru ini lebih sering digunakan hanya sebagai hiburan pada acara pesta pernikahan. Pada umumnya bila pembuat acara ingin acaranya ramai dan banyak ditonton maka mereka akan memilih untuk menampilkan pertunjukan Rentak Kudo.

Tidak heran bila Rentak Kudo yang baru ini lebih digemari semua kalangan masyarakat, alat music yang awalnya menggunakan gendang dan botol yang sederhana telah diganti dengan organ tunggal dan musiknya pun telah diganti menjadi musik house(Remix). Tidak hanya musiknya yang berubah, para penari laki-laki dan perempuan bercampur baur padahal pada versi lama penari yang ikut tari rentak kudo berada pada barisan yang berbeda. Tari rentak kudo pada masa sekarang umunya dilaksanakan pada malam hari setelah isya sampai sepertiga pagi, dan tidak semua yang hadir memilih untuk ikut menari, ada juga yang memilih untuk menyaksikan pertunjukan saja, biasanya anak muda yang memilih tidak ikut menari bergerombol dan sudah menyiapkan minuman keras. Dapat disimpulkan bahwa perubahan sosial adalah perubahan yang terjadi dalam sistem ide yang dimiliki, nilai-nilai, norma-norma, tata-susila, adat istiadat, rasa sopan santun, upacara tradisional moralitas bentuk seni baru seperti alat musik, dan jam pelaksanaan acara. 
Sintia Farsalena, Susi Fitria Dewi

Perubahan Tari Rentak Kudo Dalam Kehidupan Sosial Masyarakat

Penyebab perubahan yang terjadi bisa melalui difusi serta peniruan dan penemuan dari suku yang ada di Indonesia atau pengaruh dari luar negeri. Keadaaan inilah yang membawa pengaruh pada perilaku ataupun tata kehidupan dan kebudayaan masyarakat. Berkaitan dengan penelitian ini maka perubahan sosial budaya dilihat dari segi nilai-nilai norma dan perubahan perilaku. Dengan demikian dapat diketahui bahwa lingkungan dan segala kegiatan, pola perilaku serta tradisi atau interaksi sosial lainnya, dampak yang ditimbulkan dapat berbentuk negatif maupun positif. Dalam hal ini dampak dari pelaksanaan Tradisi Tari Rentak Kudo adalah dampak negatif, terlihat dari perubahan perilaku remaja yang ikut serta dalam acara ini tidak sesuai dengan norma dan nilai-nilai yang ada dalam masyarakat.

\section{Dampak Sosial dan Moral Pelaksanaan Acara Tari Rentak Kudo Terhadap Kehidupan Sosial Di Desa Debai}

Sebagaimana yang di kemukakan oleh Ahmadi (1990) bahwa perilaku-perilaku amoral yang melanggar norma sosial yang dilakukan remaja menyulitkan orang tua diantaranya adalah berupa minum-minuman keras. Jika dihubungkan dengan perilaku tersebut saat acara Tari Rentak Kudo yang dilaksanakan pada malam hari merupakan salah satu dampak social yang terjadi ditengah masyarakat Desa Debai dan hal tersebut adalah perbuatan yang melanggar norma-norma yang berlaku dalam masyarakat dan adat istiadat. Menurut Ahmadi (1990) minum-minuman berakohol dapat membuat orang sakit dan dampak paling kentara dari mabuk alkohol adalah perilaku agresif dan kecenderungan berperilaku menyimpang.

Soekanto dan Soemarjan (2012) mengemukakan bahwa masalah alkoholisme dan pemabuk pada kebanyakan masyarakat pada umunya tidak berkisar pada apakah alkohol boleh atau dilarang dipergunakan. Persoalan pokoknya adalah siapa yang boleh menggunkannya, dimana, kapan dan dalam kondisi yang bagaimana. Umumnya orang awam berpendapat bahwa alkohol merupakan stimulant, padahal sesungguhnya alkohol merupakan racun yang mempunyai efek pada sistem saraf. Akibatnya, seorang pemabuk semakin kurang kemampuannya untuk mengendalikan diri, baik secara fisik, psikologis maupun sosial.

Seperti yang telah dijelaskan pada uraian sebelumnya telah terjadi berbagai perilaku remaja dan pemuda dalam acara Tari Rentak Kudo yaitu minum-minuman keras, berkelahi serta mengganggu kenyamanan penari lainnya. Berdasarkan pendapat Kartono (1990) tingkah laku abnormal atau menyimpang yaitu tidak diterima oleh masyarakat pada umumnya, dan tidak sesuai dengan norma sosial yang ada dalam masyarakat. Perilaku abnormal atau menyimpang sebagaimana yang dimaksud oleh Kartono ini telah terjadi dalam pelaksanaan acara Tari Rentak Kudo yang mana 
perilaku tersebut tidak diterima oleh masyarakat pada umumnya dan tidak sesuai dengan norma yang berlaku dalam masyarakat di Desa Debai.

Meski memiliki dampak yang tidak baik saat dilaksanakan tradisi tari rentak kudo hingga saat ini masih terus dilestarikan oleh masyarakat Kerinci dan Sungai Penuh di acara pesta pernikahan, maupun acara yang diselenggarakan oleh instansi pemerintah sehingga tidak hanya orang tua saja yang bisa menari pada saat tradisi ini dilaksanakan tetapi anak-anak hingga remaja pun bisa ikut menari. Berikut beberapa dampak moral dari pelaksanaan tari rentak kudo di Desa Debai Kota Sungai Penuh:

1) Dengan diadakannya Tari Rentak Kudo pada saat pesta pernikahan maka masyarakat sekitar, baik itu masyarakat Desa Debai maupun masyarakat desa tetangga akan beramai-ramai mendatangi tempat diadakannya Tari Rentak Kudo biasanya dilaksankan didepan rumah yang sedang pesta.

2) Diselenggarakannya Tari Rentak Kudo ini membuat masyarakat merasa senang, hal ini dapat dilihat dengan antusiasme masyarakat yang datang ke tempat acara pelaksanaan Tari Rentak Kudo untuk ikut menari, ada juga yang datang hanya untuk menyaksikan dan tidak ikut menari.

3) Dengan ikut menari atau hanya menyaksikan acara Tari Rentak Kudo ini membantu menghilangkan stress bagi masyarakat yang bekerja pada siang harinya.

4) Pada masa sekarang bila acara pesta dan Tari Rentak Kudo di laksanakan selalu menyewa orgen tunggal sehingga terjadi perkembangan usaha orgen tunggal yang ada di Kerinci dan Kota Sungai Penuh dan tentu saja hal itu menumbuhkan perekonomian di bidang usaha orgen tunggal.

\section{Kontrol Sosial Dari Masyarakat Terhadap Pelaksanaan Tradisi Tari Rentak Kudo}

Kartono (1990) menyatakan kontrol orang dewasa terhadap para remaja semakin berkurang disebabkan kondisi sosial yang patologis dimana penyebab utamanya adalah faktor kecepatan perubahan sosial sehingga banyak terjadi ketidakstabilan pada sektor politik, ekonomi, pendidikan lingkungan keluarga dan lembaga-lembaga sosial di tengah masyarakat. Disebabkan oleh norma, kontrol sosial dan sanksi menjadi semakin lemah berakibat pada perilaku remaja yang tidak terkontrol. Selain itu berkurangnya kontrol sosial orang dewasa terhadap anak remaja di perkuat oleh paham individualisme dalam masyarakat. Hal inilah yang terjadi di Desa Debai, kontrol sosial dari masyarakat dan orang tua sangat lemah sehingga berbagai kenakalan terjadi terlebih ketika diadakan keramaian seperti Tari Rentak Kudo.

Awal tahun 2017 kepala desa membuat keputusan tidak tertulis tentang pelarangan melaksanakan acara tari rentak kudo pada malam hari, hanya di 
perbolehkan pada siang hari, bila terdapat pelanggaran maka akan didenda sebesar tiga juta rupiah, pengumuman ini disampaikan melalui pengeras suara masjid desa. Namun tidak terlalu di hiraukan oleh masyarakat Desa Debai yang masih melaksanakan acara tari rentak kudo beberapa bulan setelah pengumuman tersebut. Kartono (1990) mengemukakan bahwa pengendalian sosial selalu mencapai tujuan namun bisa saja gagal bahkan akan dapat melemah karena masyarakat perubahan sosial mendasar dan cepat sehingga pudarnya patokan perilaku akibat terjadinya bentrokan unsur-unsur lama dengan yang baru. Keadaan tersebut akan mengakibatkan disorganisasi sosial dan nilai-nilai maupun norma-norma semakin melemah dan tidak jelas. Maka terjadilah gangguan terhadap stabilisator perilaku kelompok. Hal ini telah terjadi pada masyarakat yaitu ninik mamak, alim ulama dan cerdik pandai tidak dapat mencapai tujuan kontrol sosial. Bahkan melemahnya kontrol sosial dimana perangkat desa tidak mampu secara tegas memberikan sanksi atas pelanggaran yang ada, dan tidak mampu melarang para pemuda dan remaja berperilaku seperti yang terjadi pada saat pelaksanaan acara Tari Rentak Kudo.

Kartono (1990) juga menyampaikan perubahan-perubahan sosial yang serba cepat dan kurangnya kesepakatan antara masing-masing anggota mengenai pola perilaku kehidupan sehari-hari mengakibatkan banyak individu yang menggunakan penyelesaian masalah "semaunya saja", acak-acakan atau anarkis, sebagaimana yang terjadi di masyarakat Desa Debai dimana perilaku remaja merupakan salah satu perubahan sosial cepat. Kurangnya kesepakatan anggota masyarakat yakni perangkat desa, alim ulama, ninik mamak, organisasi pemuda dan anggota masyarakat lainnya dalam membuat aturan terkait dengan masalah ini mengakibatkan perilaku menyimpang yang terjadi pada remaja dan pemuda di Desa Debai ini.

\section{Simpulan}

Pelaksanaan Tari Rentak Kudo di Desa Debai yang dilaksanakan pada malam hari telah terjadi perilaku remaja yang tidak sesuai dengan norma-norma sosial yang berlaku dalam masyarakat. Pada saat pelaksanaan acara ini seringkali terjadi perilaku yang menyimpang yaitu seperti minum-minuman alcohol, dan perkelahian akibat dari saling dorong mendorong saat sedang menari. Selanjutnya sebagian masyarakat merasa terganggu dengan adanya perilaku menyimpang dari para pemuda dan remaja-remaja ini karena tidak sesuai dengan norma-norma yang ada di dalam masyarakat Desa Debai. Dilihat dari dampak yang ditimbulkan oleh pelaksanaan Tradisi Tari Rentak Kudo kontrol sosial dari masyarakat Desa Debai sangat lemah dan sangat diharapkan adanya kontrol dari orang tua, pemerintah desa dan tokoh masyarakat seperti alim ulama dan ninik mamak agar tidak terjadi hal-hal kriminal yang bisa meresahkan masyarakat, namun pemerintah desa tidak bisa memberi sanksi bagi para pelaku yang 
membuat keributan dalam acara Rentak Kudo ini karena tidak adanya aturan dan kesepakatan yang tegas antara anggota masyarakat dan perangkat desa terkait dengan pelaksanaan Tari Rentak Kudo ini. Sehingga yang sangat di perlukan adalah kontrol sosial dari seluruh pihak yang ada di Desa Debai harus ditingkatkan

\section{Daftar Rujukan}

Ahmadi, A. (1990). Sosiologi Pendidikan. Rineka Cipta.

Andreas, B. B., Kadir, T. H., \& Marzam, M. (2013). Studi terhadap Adanya Dua Versi Rentak Kudo untuk Acara Pernikahan di Desa Rawang. Jurnal Sendratasik, 2(1), 91100.

Kartono, K. (1990). Patologi Sosial. Rajawali Press.

Lexy, J. M. (2005). Metodologi Penelitian Kualitatif. Remaja Rosdakarya.

Nasution. (1992). Metode Penelitian. Jembatan.

Soekanto, S., \& Soemarjan, S. (2012). Sosiologi: suatu pengantar. Jajasan Penerbit Universitas Indonesia.

Undang-Undang Republik Indonesia Nomor 25 Tahun 2008 tentang Pembentukan Kota Sungai Penuh di Provinsi Jambi. (2008).

Widiyanti, N., \& Waskita, Y. (1987). Kejahatan dalam masyarakat dan pencegahannya. Bina Aksara. 